\title{
Criminal Street Gangs: Public Perceptions of Local Gang Issues
}

\author{
Scott Christopher Mann* \\ Assistant Professor of Criminal Justice, El Paso Community College, USA
}

*Corresponding Author: Scott Christopher Mann, Assistant Professor of Criminal Justice, El Paso Community College, USA

\begin{abstract}
Juveniles and minorities living under certain social conditions are at the highest risk for recruitment into criminal street gangs. Hispanic and female recruitment into criminal street gangs is rising. Involvement in criminal street gangs result in social rejection and lost opportunities for one's future. Research in this study focused mainly on criminological theory and its relationship to criminal street gangs. It is not known to what extent the public is familiar with the underlying causes and risk associated to juvenile gang recruitment. The purpose of this study was to examine public opinion on criminal street gangs, focused mainly within the El Paso, Texas region. The study group was restricted to enrolled students at El Paso Community College. Results of the study suggest that within a socially organized community, community members have a decent understanding of modern criminology and the negative underlying social impacts which influence juvenile delinquency and gang involvement.
\end{abstract}

Keywords: Juvenile Delinquency, Street Gangs, Negative Labeling, Social Learning

\section{INTRODUCTION}

Juvenile delinquency and its connection to criminal street gangs are a growing problem in the United States. Street gangs predominately exist in lower-income areas with urban areas of decay. Hispanic gangs are on the rise, and more females are joining the gang lifestyle. These criminal groups encourage delinquency, violence, and anti-social behavior. Such behavior typically results in social rejection and lost opportunities for any future intervention efforts. There are successful and progressive governmental intervention treatments available if local law enforcement, the juvenile courts, and their attached communities are willing to address the gang problems cohesively.

\section{DESCRIPTION OF THE PROBLEM}

There are vast amounts of diverse sources dedicated to youth gangs, gang prevention and intervention programs, including strategies to suppress gang involvement and criminal delinquency. This article will also describe some criminological theories to which this author believes is related to youth gangs. This article will explore issues related to minorities, low-income areas, poverty and some promising strategies in delinquency prevention. Would an increase in public understanding of local street gangs influence their satisfaction in the current response by local government? Also, does residency impact public perceptions about street gang affiliation? Therefore, it is not known, or to what extent the public in El Paso recognizes social issues related to local criminal street gangs. The purpose of this research is to explore public opinion on criminal street gangs in the El Paso, Texas area and to identify and explore a better understanding of youth gang problems.

\section{LITERATURE REVIEW}

There are several criminological theories and ample publications which attempt to explain deviant behavior. Understand, crime theory specifically relates to the science and politics of the time. As politics change, so does its influence on research related to crime. From a broad perspective, we have witnessed the start of early criminology during the classical period $\left[17^{\text {th }}\right.$ Century] develop along with biological sciences well within the early 1900s. As psychology gained acceptance, we began to see crime theory focus on how a person behaves in relation to environmental and social conditions. Today, criminologists believe that criminal behavior is the product of a complex interaction between biology and environmental or social conditions. 
The typical street gang in America can be easily identified as being anti-social (Maxson, Matsuda \& Hennigan, 2009). The gang culture encourages delinquency and antisocial behavior (Knight, Losoya, Cho \& Williams, 2012). Gangs have a higher level of collective violence when they are more hierarchically organized as a gang (Sheley, Zhang, Brody \& Wright, 1995). They establish their own norms and social identity separate from the normal social structures of main-stream society and tend to discount the social and behavioral norms of the main-stream society. As a result, their activities are deviant to social norms and usually criminal. Therefore, what is important to a gang and what influences a gang member has little to do with the social and legal threats posed against them by the government. The study from Maxson, et al. (2009) concluded that threats of legal sanctions and enhanced penalties against gang members have little influence on their choices on committing crimes. The following paragraphs associate selected criminological theories related to delinquency and gangs.

\subsection{The Classical School}

Cesare Beccaria (1764) wrote a book "On Crimes and Punishment" in an effort to understand criminality and deviant behavior. Beccaria believed in free-will, which eventually led the way to the Rational Choice theory. The Rational Choice theory took into consideration that people make rational choices by weighing the risks v. rewards. However, biological science has shown that people with lower intelligence act more on instincts and emotion and exhibit lower self-control. Rational thought requires maturity and intelligence in weighing options and planning on variables to determine the best option. This led the way to the positive school.

The positivists expanded on rational choice in believing that human behavior was determined by a person's biological, psychological, and social traits (Delaney, 2014). Most of the stringent biological theories suggesting the "born Criminal" have since been dismissed. Today, the biological approach considers personality and environmental influences on biological traits, which increase the probability for deviance. In this intelligence-based theory, the basic assumption of a criminal is that they are too dumb to make rational choices. As discussed above, this thought also considers low self-control and at worst, insanity.

\subsection{Labeling Theory}

Labeling theory focuses on the social responses to crime and deviance. It suggests that criminal prosecution and intervention impacts an individual's immediate social networks (Bernburg, Krohn \& Rivera, 2006). However, being given a "criminal status" by society actually increases the probability that this "label" will push a person into deviant social groups (Bernburg, et al., 2006). In other words, tagging a juvenile (societal reaction to crime) as a criminal can push them further into the gang life.

Gangs provide shelter and social support to other delinquents who engage in criminal activity (Bernburg, et al., 2006). We see adolescents labeling each other in junior high school and avoid those who are defined by a different label. Once an adolescent is officially labeled as a delinquent or becomes known as a criminal or "gangster" by society, they will seek out and socialize with others who will accept their label. Official labeling by the government increases the likelihood of social mistrust and rejection, as the labeled juvenile will likely be excluded from conventional social groups in the community (Bernburg, et al., 2006). However, it is important for the author of this paper to note that not all negative labeling results in secondary deviance or delinquency. A juvenile's strong attachment to a positive home environment may reduce the risk of long-term offending.

Negative labeling could actually create a self-fulfilling prophecy for those who fall under a delinquent label, but there are also studies from theorists regarding "positive labeling," where positive labeling fosters conformity (Brezina \& Aragones, 2003). Frank Tennebaum's Crime and Community [1938] examined the process of negative labeling. According to Bartollas \& Schmalleger (2008), Tennenbaum argued that once a juvenile received negative labeling from the authorities, the juvenile would be further treated differently by the authorities and the community. This also changed the way the juveniles would see themselves, resulting in further deviance and delinquency (Bartollas \& Schmalleger, 2008). Tannenbaum [1938] made recommendations that to lessen the deviancy, authorities and the community needed to reduce the dramatization of negative labeling against the juvenile (Bartollas \& Schmalleger, 2008).

In 1951 and again in1967, Edwin Lemert examined primary deviation, as being an individual's behavior, and secondary deviation being society's response to that behavior (Bartollas \& 
Schmalleger, 2008). Lemert [1967] believed that the primary deviation had only marginal implications, whereas the secondary deviation created a stigma (Plummer, n.d.). This would alter the social role and attitude of those being negatively labeled (Plummer, n.d.). It is the negative labeling by control agencies that generate further crime (Plummer, n.d.). Lemert identified the process as:

- Primary deviation;

- Social penalties;

- Further primary deviation;

- Stronger penalties and rejection;

- Further deviation, possible hostility, and resentment towards those doing the penalizing;

- Loss of tolerance and formal action from the community;

- Strengthening of the deviant conduct as a reaction to the formal action, and;

- Adjustment and acceptance to one's social status as a deviant (Bartollas \& Schmalleger, 2008).

According to Jackson \& Hay (2013), the labeling process turns those marginal offenders into career offenders. However, prior research on labeling had lacked focus on the key social process variables that condition the effects of labeling on criminality (Jackson \& Hay, 2013). Starting in 1993, Jackson \& Hay (2013) conducted a study in five U.S. cities that examined the impact of a positive family environment on the official negative labeling of high-risk early adolescents [Between age 11-13]. They hypothesized that a strong family environment would diminish the effect on a juvenile's subsequent delinquency; as such, strong positive familial ties would afford the juvenile a constructive means to acknowledge the shame and move on towards social integration. The principal interest of the study was to observe whether an arrest-delinquency relationship was moderated by the degree of the juvenile's family attachment (Jackson \& Hay, 2013). Their findings showed that high exposure to a positive family attachment reduced the negative impact of official labeling for these young at-risk youth (Jackson \& Hay, 2013).

To further this point, a two-year study by Chambliss [1973] followed and examined two groups of adolescent delinquents receiving different reactions of their delinquency by the community. According to Brezina \& Aragones (2003), one group was negatively labeled for their delinquency, while the other group received positive labeling. In the study, the lower-class adolescents receiving the negative labeling were known as the "Roughnecks," and the other group known as the "Saints" were made up of middle-class youth. In the study, Chambliss observed that the Roughnecks were targeted more by the police, while the Saints were generally viewed favorably (socially) by the police and the community (pp. 517-518). Although the positive labeling did not reduce the delinquency of the Saints in the short-term, the long-term social conformity had been observed (Brezina \& Aragones, 2003). In other words, the Saints eventually grew out of their delinquent behavior after high school, while the Roughnecks continued criminal behavior into their adult life (Brezina \& Aragones, 2003).

There is something to take from positive labeling for law enforcement, the community, and the criminal justice system. When the author of this paper was a child, his father used to tell him (frequently) "You are a good boy, but what you did was bad." Interestingly, research suggests that negative official labeling increases the long-term impact of high-risk behavior and delinquency. This author is not suggesting a community's "denial" of delinquency by a good child, but rather addressing the problem, instead of the person, per se, may increase the opportunity for the adolescent to remain within their community's social environment and participate in the rehabilitation and corrective process. The criminal justice system's official labeling and persistent negative attention to the adolescent delinquent "gangster" may be creating a self-fulfilling prophecy for the adolescent, who ultimately is just a kid seeking social acceptance - even if it is in an anti-social environment.

\subsection{Social Theories}

Sociological theories best fit within the nature of gangs. These theories are grounded in the belief that deviance is a product of environmental factor influences. A well-known crime theory called the "Chicago School" came out in the 1930s. Basically, urban areas experience more crime than nonurban areas because of environmental factors related to high-density and low-incomes. These factors 
increase broken homes and social disorder, which in turn increase deviance. Also, in these areas, social cohesion breaks down causing social disorganization. This creates weaker social bonds among residents of these areas.

The Anomie/Strain theory suggests that the normal social constraints and rules break down in socially disorganized neighborhoods. Because of this, socially normal behavior is no longer the norm. The new pattern becomes anti-social behavior and deviance. According to Merton (1938; 1968), anomie refers to the breakdown of social norms and rules no longer control the activities of individuals living in these environments.

Early strain theories, such as Merton's 1938 version have been largely criticized for their limited scope in focusing mainly on the lower-class boys in urban environments. However, strain theory provides one of the best explanations for juvenile criminal gang activity. According to Akers \& Sellers (2013), Strain Theory states that crime is a result of the strain placed on individuals who are not able to achieve middle-class norms through any legitimate means. Agnew's $(1985,1992)$ General Strain theory considered gender, race, class and other differences in a broader approach.

General Strain theory is a social-psychological theory that argues that one's responses to strain are shaped by the nature, intensity, and duration of the strain (Broidy, 2001). Strain triggers negative emotions that require coping mechanisms to deal with the emotion (Broidy, 2001). If legitimate coping strategies are unavailable, an individual may adopt illegitimate coping strategies (Broidy, 2001). There is a link to crime when a person fails to achieve positively valued goals, combined with the removal of positively valued stimuli, and the presentation of negative stimuli (Broidy, 2001). When there is a lack of opportunity, a lack of social control in disorganized neighborhoods, easy access to deviant peers, an individual is in a higher risk for adopting illegitimate coping strategies and delinquency (Broidy, 2001). Negative life events are correlated with delinquency and drug use, which reduces attachment (Broidy, 2001).

After Merton [1938], Albert Cohen (1955) applied Subcultural theory explicitly to juvenile street gangs that had not been addressed by Merton's strain theory. Cohen stressed that middle-class standards imposed on lower socio-economic class youth created a status deprivation among these youth - pushing them into juvenile gangs (Akers \& Sellers, 2013). In turn, juvenile gangs aspire to the standards opposite of the middle class (Akers \& Sellers, 2013). Cohen argued that gangs do not aspire for monetary gain, but rather status and respect (Akers \& Sellers, 2013).

Agnew's General Strain theory $(1985 ; 1992)$ looks at crime at the micro-level instead of the macroview. Agnew identified three types of strain that produce deviance. First, when a person fails to achieve positively valued goals, there is a gap between the aspirations and the opportunities available to the individual, leading to disappointment and resentment (Akers \& Sellers, 2013). Second, there is the removal of positively valued stimuli (Akers \& Sellers, 2013). This involves all of the negative stress experienced by the individual, such as the loss of a loved one, school suspension, or moving to a new town. The third type of strain identified by Agnew (1992) is an individual's confrontation with negative stimuli (Akers \& Sellers, 2013). This may include child abuse, being picked on at school, or negative encounters with the police. According to Agnew (2012), a juvenile will react to these negative stimuli through illegitimate means because they do not have any other choice. They have no legitimate means to avoid them.

The labeling theory focuses on the social responses to crime and deviance. Labeling theory suggests that criminal prosecution and intervention impacts an individual's immediate social networks (Bernburg, et al., 2006). However, being given a "criminal status" by society actually increases the probability that this "label" will push a person into deviant social groups (Bernburg, et al., 2006). In other words, tagging a juvenile (societal reaction to crime) as a criminal can push them further into the gang life. Negative labeling could create a self-fulfilling prophecy for those who fall under a delinquent label, but there are also studies from theorists regarding "positive labeling", where positive labeling fosters conformity (Brezina \& Aragones, 2003).

The violent victimization of so many adolescents is a major problem in the United States. In 2000, about six out of one-hundred children, between the ages of 12-19 were violently victimized (Kaylen $\&$ Pridemore, 2011). This was higher than any other age group in the country (Kaylen \& Pridemore, 2011). The Social Disorganization theory attempts to partially explain why there is not an even distribution of this violence across the country. 
Members living in communities that are connected to each other have lower rates of delinquency (Kaylen \& Pridemore, 2011). In this type of environment, there is a greater level of socialized supervision and opportunity for children. However, the geographical make-up of a community also impacts delinquency and victimization rates. For example, a densely populated community will have an increase in victimization rates, compared to other areas (Kaylen \& Pridemore, 2011). The more population density in a smaller area, the more disorganization is observed; resulting in less oversight, supervision, and opportunity. Combining these factors, such as broken homes, drug abuse, and low incomes, this makes for a breeding ground for delinquency and gangs.

There is a problem with associating urban gangs to Social Disorganization theory, as not all gangs are urban. There have been studies indicating a migration of gangs outside of urban areas. Some of the reasons for the migration involved drug distribution, other illegal activities, recruitment, and avoidance of law enforcement (Egley \& Howell, 2012). However, the initial development of the gang may have likely originated within the urban environment. Once the gang became more organized, profit became a motive causing the expansion of the gang into suburban areas. Additionally, there are also other factors to consider in which gang members relocated individually to other locations for legitimate social reasons. For example, a gang member may move with a family for other job employment opportunities (Egley \& Howell, 2012). Gangs are also evolving into more ruthless criminal organizations by getting involved in drug and human trafficking, extortion, and affiliations to the major international drug cartels (Egley \& Howell, 2012).

Social Learning theory describes how deviant behaviors are learned through interaction with others, such as the social structure in which one lives around. This includes the family and one's peer group association (Mui, Sales \& Murphy, 2013). These interactions impact one's values and experiences, which contribute to one's behavior (Mui, et al., 2013). These social interactions also provide the learning environments that define one's normal behaviors (Lee, Akers \& Borg, 2004). Akers [1998] argued that Differential Association, such as a gang's social structure or system affects the rate of crime and deviance (Lee, et al., 2004). Akers [1998] also argued that the "differential location in the social structure," such as age, social groups and social categories will affect crime rates (Lee, et al., 2004).

An individual's socialization with a group will have its own controls that will regulate, and even encourage deviance (Lee, et al., 2004). As described earlier in this paper by Maxson, et al. (2009), the typical street gang in America can be easily identified as being anti-social. Akers [1998] identified this variable as a "theoretically defined" construct involving a group of people that fall into class oppression (Lee, et al., 2004). Gang members are generally viewed as those coming from lower-class environments. Social Learning from this class level creates interpersonal stresses (Lee, et al., 2004). This is generalized, but it includes negative family relationships, financial hardship, and in more cases - role models that are more prone to criminality (Lee, et al., 2004).

Generally, research has found that neighborhoods with higher proportions of single-parent households have higher crime rates (Lee, et al., 2004). Many lower-income and single-parent homes lack the presence of a male role model (Lee, et al., 2004). It is also commonly known that low-income neighborhoods are more likely to have a higher rate of criminal street gangs. As will be discussed further in this paper, broken homes are considered a major cause of persistent delinquency (Bartollas \& Schmalleger, 2008). Single-parent households have less supervision, mentorship, and control over children, which increases the risk of adolescent anti-social peer group socialization in low-income neighborhoods.

\subsection{General Strain Theory}

Early strain theories, such as Merton's 1938 version have been largely criticized for their limited scope in focusing mainly on the lower-class boys in urban environments. However, Strain Theory provides one of the best explanations for juvenile criminal gang activity. According to Akers \& Sellers (2013), Strain Theory states that strain occurs to individuals who are not able to achieve middle-class norms through any legitimate means. Agnew's $(1985 ; 1992)$ General Strain theory applied to gender, race, class, and other differences into account in a broader approach.

General strain theory is a social-psychological theory which argues that individual responses to strain are shaped by the intensity, nature, and duration of the strain (Broidy, 2001). Strain may trigger negative emotions which require coping mechanisms to deal with the emotion (Broidy, 2001). When legitimate coping strategies are unavailable, an individual may adopt illegitimate coping strategies 
(Broidy, 2001). Combined with the removal of positively valued stimuli and the presentation of negative stimuli, there is a link to crime when a person fails to achieve positively valued goals (Broidy, 2001). When there is a lack of opportunity, a lack of social control in disorganized neighborhoods, easy access to deviant peers, an individual is at a higher risk for adopting illegitimate coping strategies and delinquency (Broidy, 2001). Negative life events are correlated with delinquency and drug use, which reduces attachment (Broidy, 2001).

The author of this paper believes Strain Theory provides a better explanation for the purpose of juvenile gangs. Generally, street gangs do what they do because it is the only means they have available to them to accomplish their goals. Other than some financial needs, gangs really have nothing to gain or lose in society by committing crimes, so they commit delinquent and criminal acts simply because the ends justify the means within their delinquent subculture.

\subsection{Minority and Gender Issues}

It has been statistically proven that when comparing genders, crime and deviance is higher for males (Lee, et al., 2004). However, females do participate in the gang life. According to Bartollas \& Schmalleger (2008), victimization is generally the first step for an adolescent female into the criminal justice system. However, females are less involved in adolescent delinquency because their "sex-role" socialization creates deeper social bonds (Bartollas \& Schmalleger, 2008). In the older El Paso Hispanic culture, there are different expectations for female youth. Females are generally raised to be more dependent on others and are more closely supervised than males (Bartollas \& Schmalleger, 2008). This creates a larger stigma on females who enter a gang because of their gender-roles. For those that do, there is a common theme showing prior victimization, such as rape, abuse, broken homes and abandonment (Bartollas \& Schmalleger, 2008). It is important to note that there is evidence that many adolescent girls turn to gangs for personal protection to avoid violence from others (Miller, 1998). Also, general studies suggest that females who enter gangs tend to leave the gang life sooner. This includes factors involving life changes, such as marriage, having a baby and income needs (Bartollas \& Schmalleger, 2008).

Broken homes (single-parent homes; divorce, abuse, conflict, etc.) are considered a major cause of persistent delinquency (Bartollas \& Schmalleger, 2008). Although this impacts female adolescents more, it impacts males as well (Bartollas \& Schmalleger, 2008). According to Bartollas \& Schmalleger (2008), poverty is a major problem with children and delinquency. Although AfricanAmericans represent about 18\% of the population in the United States [United States Census Bureau, 2014], they had a poverty rate of 32\% of the population in 2002 (Bartollas \& Schmalleger, 2008). By 2012, poverty among African-Americans remained at relatively the same level (Desilver, 2014). Noticeably, the Hispanic population in the United States has quintupled over the past 40 years (Desilver, 2014). Since 1972, the poverty rates for Hispanic families have risen slightly from about $22 \%$ to a little over $25 \%$ (Desilver, 2014). It is important to note that both minority groups mentioned have over double the number of families, per capita, living in poverty than Caucasian families (Desilver, 2014). There is no surprise that many in our society, depending on the region, view the typical street gang member to be an ethnic minority adolescent. According to a 2006 Arizona study, $62 \%$ of reported gang members in that State were Hispanic (Knight, etal., 2012).

Adolescent ethnic minorities, in particular, tend to search for their cultural identity through family relationships and ethnic-similar peer groups (Knight, etal., 2012). Mexican American youth are twice as likely to have some affiliation to a gang, compared to other ethnic groups (Knight, etal., 2012). This may be explained through recent generations of mass migration into the United States. In a recent study (2012) conducted on Mexican-American juvenile offenders, it was discovered that the search for one's "ethnic-identity" among Mexican-American youths was the highest during early adolescents (Knight, etal., 2012). With age, delinquency generally declined, except for those who joined a gang (Knight, etal., 2012). An interesting discovery on this study discovered that ethnic identity affiliation was less for those adolescents that came from third [or more] generation immigrant families (Knight, etal. 2012). The combination of factors involved with a Hispanic adolescent coming from an immigrant family, a broken home, and one's search for cultural identity may lead towards the affiliation to a Hispanic gang. Also, the sub-culture of "gang-life" increases the risk of life-course offending well into adulthood. 


\subsection{El Paso Street Gangs}

According to the Texas Department of Public Safety's Texas Gang Threat Assessment (2017), there are roughly 100,000 gang members in the state. It is becoming more common to see local street gangs working more closely with the Mexican drug cartels, as well as opposing gangs in the illegal drug trade. In the El Paso area, the Barrio Azteca gang is the largest known transnational gang working between the Juarez drug cartel and local gangs to advance cross-border smuggling and trafficking in illegal drugs (pp. 3-13).

In 2017 the El Paso Police Department applied for a Texas Anti-Gang Program (TAG) grant, through the Criminal Justice Division of the Texas Governor's Office. According to the City of El Paso's Agenda Item Project Summary (August, 2017), The El Paso Police Department (EPPD) reported El Paso has 330 active gangs and 6,460 gang members. The EPPD claimed in the abstract that gang activity in the El Paso area was on the rise and citing information from the 2017 Texas Gang Threat Assessment. Some of the more commonly known local street gangs mentioned operating in the El Paso area were Surenos, Crips, Folk Nation, Bloods, and Barrio San Juan. The main purpose for the TAC grant was to provide an enhanced law enforcement response to gang activities, more cooperation and reporting of gang data to participating agencies and the State of Texas (pp. 18-19).

\subsection{Legal Responses and Prevention to Criminal Street Gangs}

For several decades, traditional policing methods and public policies have focused on gang suppression and deterrence, rather than focusing more so on prevention and intervention (Decker, 2003; Green \&Pranis, 2007; Klein \&Maxson, 2006). Common gang strategies by law enforcement have typically involved specialized gang suppression units, multiagency task forces, and gang injunctions (Decker, 2003; Green \&Pranis, 2007; Klein \&Maxson, 2006). The author of this paper has personally participated in several of these anti-gang law enforcement activities, and in the long-term, they were completely ineffective in reducing gang affiliation and neighborhood crime.

Many states have also passed special laws and created special prosecutorial units focused on combating criminal gang activity. For example, in 1989, California passed the "Street Terrorism Enforcement and Prevention Act" (Maxson, et al., 2009). Some of the penalties for this act included increased penalties for criminal gang activity and trying certain juveniles as adults (Maxson, et al., 2009). Many other states have passed similar measures. On the national level, the Gang Abatement and Prevention Act [2007] increased law enforcement funding and established harsh federal penalties for gang-related crimes (Maxson, et al., 2009). An interesting earlier study by Klepper and Nagin [1989] found that neither the severity of punishments or certainty of being punished influenced criminal behavior. It was socialization and moral considerations that best predicted one's criminal tendencies (Tonry, 2011).

Many decades ago, status-offense laws and ordinances were passed to thwart juvenile gang activity. The United States Supreme Court has weighed in on several cases related to anti-loitering activities. For example, in the case of Shuttles worth v. Birmingham,1969 the City of Birmingham created an ordinance prohibiting a person from loitering in a public place after being told by a police officer to move on. In the case of Papachristou v. City of Jacksonville, 1972 the City of Jacksonville created an ordinance prohibiting persons from wandering or loitering without any lawful purpose. In both cases, the Supreme Court found these ordinances to be unconstitutional (OJJDP, 2003). There have been common rulings of unconstitutionality when these laws and ordinances provide a vague definition to meet the requirements of lawlessness.

In what would be considered minor crimes alone, States have created mini-RICO (Racketeer Influenced and Corrupt Organizations Act) statutes to address local criminal enterprises violating state law. Some of the crimes targeted under State RICO statutes include prostitution rings, fencing operations, and drug distribution. Under the State RICO statutes, prosecutors can prosecute patterns of criminal acts committed by groups of people [enterprise], who participated either directly, or indirectly, in the criminal activities within the group (Rebovich, Coyle \& Shaaf, 1993). Prosecutors can also pursue these criminal enterprises civilly, such as civil injunctions (Rebovich, et al., 1993).

Since the inception of these statutes in the 1980s, State conspiracy laws have been adopted to combat criminal gangs. For example, in 2003, the El Paso County Attorney's Office obtained a civil gang injunction against the Barrio Aztecas [criminal prison and street gang] prohibiting thirty-two members 
of the gang from associating with each other (O'Deane, 2011). The injunction included a 10:00pm curfew and barred these members from entering certain establishments within a designated safe zone (O'Deane, 2011). In Texas, violations of these injunctions fall under the Civil Remedies Code and may result in punitive fines and jail sentences. In 2010, Harris County obtained a gang injunction against the "Bloods" and "Crips" gangs who were causing problems and selling drugs at a large apartment complex in the county (O'Deane, 2011). As a government crime control strategy, it is becoming more common to the growing use of civil gang injunctions across the country (O'Deane, 2011). This might work for adult gang members, but juvenile delinquents in Texas are deemed to be a child in need of supervision, and in most cases, they are not subject to adult criminal prosecution, especially RICO statutes.

For many states, juvenile laws are designed to combine community safety, while providing delinquency with monitoring and treatment (McElrath, Chriqui, Bates \& McBride, 2009). Again, juvenile offenders are in need of further supervision. The goal of juvenile law is the eventual reintegration of the juvenile back into the community (McElrath, etal., 2009). The problem with this is that the juvenile justice system does not get involved until after-the-fact. Adolescent delinquency begins when a juvenile's connection to the existing social order is damaged, or broken (Bartollas \& Schmalleger, 2008).

Beccaria [1764] believed that crime occurs when the rewards outweigh the anticipated risk and appropriate deterrence was the solution to crime (Jacobs, 2010). The problem with deterrence is that it does not sway moral decisions from the population that sits on the two extreme ends of the continuum. "Good people" are not deterred by criminal punishment, as they have no intention to be immoral, nor violate social rules or norms of goodness, whereas "Bad people" reject social norms and laws. Sanctions mean little to these "Incorrigible" offenders because they are impervious to dissuasion (Jacobs, 2010). According to Jacobs (2010), deterrence is intended for "deterrable" offenders. It is this author's opinion that gang members may fall within the spectrum of "deterrable" and incorrigible offenders, based on the depth and length of their involvement within the gang. Group interaction among co-offenders emboldens delinquency and promotes invincibility (Jacobs, 2010). The only way to deter incorrigible people from criminal activity is to separate them from society. As a general comment, the Routine Activity theory argues that severe punishments have little to no effect. With this said and known, the criminal justice system still continues to pursue such punishments and injunctions.

For the sake of argument, and in order to provide some support and balance to traditional police strategies, Gary Becker's (1968) book Crime and Punishment: An Economic Approach, there was an assumption that criminals take odds of detection outside of their control, such as monitoring police efforts, and then weigh the chances of being caught (Akerlof\& Yellen, 1994). Becker also believed that the intensity and resources provided to police efforts to catch criminals would increase the probabilities of apprehension (Akerlof\& Yellen, 1994). However, police cannot make a viable impact on community crime without the assistance of the community. The problem with gangs is that they are committed to territory control and dissuade members of the community from cooperating with the police (Akerlof\& Yellen, 1994). As crime rises, police become less effective, and communities become more alienated from the police (Akerlof\& Yellen, 1994).

\subsection{Promising Strategies}

It is commonly understood that the job of government is to set the budgets, create the laws, penalties, and procedures whereby offenders are apprehended, indicted, sentenced, and paroled (Akerlof\& Yellen, 1994). So, the attractiveness of outside economic opportunities is a key determinant of the costs and benefits of criminal activity (Akerlof \& Yellen, 1994). However, gangs push the community to its level of tolerance related to their activities (Akerlof \& Yellen, 1994). As discussed, the criminal justice system is and should be seen as the last line of defense. To deal effectively with street gangs, non-traditional crime strategies and social programs aimed at strengthening community institutions will begin the process of dealing with this serious problem. As written by Jones (2004), Sir Robert Peel [1829] known by law enforcement as the father of modern-day policing suggested in his Principles of Policing that the community and the police are the same. Peel also believed the "Police must secure the willing co-operation of the public in voluntary observation of the law to be able to secure and maintain the respect of the public" (pp. 30-32). 
Law enforcement can openly engage in community and problem-oriented policing strategies, which will improve the rapport between the police and the community (Akerlof \& Yellen, 1994). Together, and under the leadership of the police, these community problems can be addressed. Local and State governments should also budget funds to enhance economic opportunities for the lower class in America. Lower-class juveniles identified as at-risk for joining gangs should be given access to training programs that help them to integrate into middle-class goals and means. Community mentors properly trained to work with gang members will ease the delinquency within a community. Getting at-risk juveniles involved in community activities will ease delinquency within a community. Providing job opportunities and technical skills training for at-risk youth will also ease delinquency within a community. The author of this paper believes the road to success is about opportunities and relationships.

In fairness, some programs do work. The U.S. Department of Labor's Job Corps was created under the Title I-C of the Workforce Investment Act of 1998 (Job Corps, n.d.). The purpose of the Job Corps is to provide outreach and develop at-risk youth to prepare them for career success. The Job Corps offers "GED" training and other vocational studies to enhance one's employability of young people. For example, in 2011, about $67 \%$ of its graduates obtained job placements (Job Corps, n.d.). Considering the alternative, it has been successful in providing opportunities to lower-class youth. The author of this paper believes this program needs to be expanded.

The Department of Justice has long provided crime prevention assistance programs focused on combating juvenile crime and violence. The problem with understanding program effectiveness is that these programs are funded to local governments and data collection is difficult, at best. In other words, it is difficult to measure community success. According to Sherman, et.al. (1998), the following are examples of programs that have been described as being successful:

- Frequent home visits to infants aged 0-2 by trained nurses and other helpers;

- Preschool and weekly home visits by teachers;

- Family therapy and parent training about delinquent and at-risk preadolescents;

- Training and coaching in thinking skills for high-risk youth using behavior modification techniques;

- Ex-offender job training for those no longer under government supervision;

- Civil injunctions against landlords for not addressing drug problems on their premises;

- Extra police patrols in high-crime hot spots;

- Repeat offender programs (ROPE) that monitors high-risk offenders, and;

- Rehabilitation programs for offenders using treatments appropriate to risk factors (p. 7).

According to Sherman, et al. (1998), the following describes some examples of what is promising in reducing juvenile delinquency:

- Community and problem-oriented policing strategies;

- Police showing greater respect and politeness of suspicious persons;

- Gang monitoring by community workers, probation and police officers;

- Community-based mentoring by Big Brothers/Big Sisters of America;

- Community-based afterschool recreation programs;

- "Schools within schools" programs that group students into smaller units;

- Job Corps residential training programs for at-risk youth;

- Moving urban public housing residents to suburban homes;

- Establishing enterprise zones to reduce area unemployment, and;

- Intensive supervision and aftercare of juvenile offenders (p. 10).

\section{Methods}

Quantitative results of this study included a student survey containing 16 questions related to four issues: personal observations of street gangs in El Paso, factors contributing to juvenile criminal street gang membership, preferred methods to reduce or combat juvenile street gang membership in El Paso, and satisfaction with local government preparedness. This survey was randomly administered to 
enrolled students attending courses at El Paso Community College. Quantitative data from the survey was collected and analyzed to identify patterns of public perspectives in relation to El Paso street gang issues.

\subsection{Data Analysis, Design and Procedure}

Several reliability tests were used to assess the reliability and internal consistency of the survey's scaled items. In Table $2(\mathrm{Q} 2-\mathrm{Q} 7)$ and Table 3 (Q 8 - Q12), the Friedman Test for Repeated Measures was used to evaluate the differences between the repeated samples. In Table 4, the MannWhitney U Test was used for survey questions Q13 and Q14, as the survey items were posed as opposing statements. This non-parametric test was used to compare the two-sample means coming from the same population of respondents to determine if the two-sample means were equal or not. In Table 5, the Spearman's Rho was another non-parametric test used to measure the strength of correlation between the two variables for survey questions Q15 and Q16, having been posed as supporting statements.

\subsection{Survey Design}

This survey was administered with voluntary student participation of random courses taught by multiple faculty across several disciplines during the Spring 2019 semester at El Paso Community College. A total of $178(N=178)$ respondents provided voluntary informed consent to engage in the survey. Minors were not allowed to participate. Participating respondents were instructed on confidentiality and the purpose of the survey. The survey questions were posed to the respondents with Likert scaled level responses: (1) strongly disagree, (2) disagree, (3) not sure, (4) agree, and (5) strongly agree.

In order to ensure a reliable and valid survey instrument, the survey was examined by several independent sources familiar with both survey instruments. The survey instrument was also evaluated by the El Paso Community College Institutional Review Board for face validity and content. Finally, the survey was reviewed by several college faculty familiar with the research topic for constructive feedback. A Cronbach's alpha reliability test on questions Q2 - Q12 demonstrated reliability in cumulative responses given by the test group. The resulting " $\alpha$ " coefficient of reliability ranges from 0 to 1 in providing an overall assessment of a measure's reliability. The closer the results to 1 , the more likely the items in the survey have a shared covariance and probably measure the same underlying concept. If the results are less than .05 , underlying concepts formed by the grouped questions and answers cannot be logically concluded on a broader scale.

\section{RESULTS}

The following are results of the analysis of the public survey. Sixteen survey questions were grouped into four categories: personal observations of street gangs; factors contributing to juvenile street gang membership; preferred methods to reduce or combat juvenile street gang membership, and; public opinion on leadership, government and community preparedness. A Cronbach's alpha reliability test was used to provide an overall assessment from survey questions Q2 - Q12 $(N=178, \alpha=.714)$. The following tables also include each of the questions taken from the Student Survey. The mean score for each question indicates a numerical value on the Likert scale from 1 to 5 (strongly disagree $=1$, disagree $=2$, not sure $=3$, agree $=4$, and strongly agree $=5$ ). The observed $N$ represents the number of responses to the question.

Table 1 represents a geographical breakdown of residence self-described by the survey respondents living from within the El Paso, Texas area. The subsequent Tables (Table 2- Table 5) reflect the independent survey questions within their topic groupings, including the group testing methods and results:

Table1. About you

\begin{tabular}{|l|l|l|}
\hline \multicolumn{1}{|c|}{ Variable } & N & \multicolumn{2}{|c|}{$\%$} \\
\hline Q1: Although I may have relocated, most of my residency in El Paso has been in the: & 36 & $19 \%$ \\
\hline Region 1: Lower Valley & 76 & $41 \%$ \\
\hline Region 2: East Side & 18 & $10 \%$ \\
\hline Region 3: North East & 21 & $12 \%$ \\
\hline Region 4: Central & 33 & $18 \%$ \\
\hline Region 5: West Side / Upper Valley & \\
\hline
\end{tabular}

Survey respondents were asked which area of El Paso, Texas they consider their residence. 
Table2. Personal observations of street gangs in El Paso

\begin{tabular}{|c|c|c|}
\hline \multicolumn{3}{|c|}{$\begin{array}{l}\text { Freidman Test for Repeated Measures } \\
\text { The } X_{r}^{2} \text { statistic is } 169.7(4, N=178) \text {. The } p \text {-value is }<.00001 \text {. The result is significant at } p<.05 \text {. }\end{array}$} \\
\hline Variable & $M$ & $S D$ \\
\hline Q2: I believe criminal street gangs in El Paso are a serious problem. & 3.3 & 1.06 \\
\hline Q3: I would say that gangs in El Paso a more of a problem today than in the past. & 2.76 & .94 \\
\hline Q4: Female gang membership in El Paso is increasing. & 3.06 & .77 \\
\hline Q5: Youth are at the highest age risk for gang recruitment in El Paso. & 3.94 & .91 \\
\hline Q6: Street gangs in El Paso focus most of their activity on drug related offenses. & 3.75 & .76 \\
\hline Q7: Due to street gang activity, there are parts of town that I will intentionally a & 3.16 & 1.21 \\
\hline
\end{tabular}

In Q5 and Q6, respondents generally agreed youth are at the highest risk for gang recruitment, and El Paso gang's heavy involvement in drug-related offenses. In Q3, respondents did not share any noticeable concerns for street gangs being a serious problem in El Paso. Most respondents did not agree that gangs in El Paso are becoming a larger problem today than in the past. Region 5 residents shared the strongest agreement $(M=4.5)$ to gangs being a serious problem in El Paso. Most respondents did not find any cause, or were generally unsure for having travel concerns within the El Paso area. Region 3 and 4 residents shared the strongest agreement $(M=4.1, M=4)$ in perceptions of increasing female gang membership in El Paso. The reliability measurements for these survey results were statistically significant at $p<.05$.

Table3. Personal observations of street gangs in El Paso

\begin{tabular}{|c|c|c|}
\hline \multicolumn{3}{|c|}{$\begin{array}{l}\text { Freidman Test for Repeated Measures } \\
\text { The } X^{2}{ }_{r} \text { statistic is } 37.5112(4, N=178) \text {. The } p \text {-value is }<.00001 \text {. The result is significant at } p<.05 \text {. }\end{array}$} \\
\hline Variable & $M$ & $S D$ \\
\hline Q8: Ethnic minority. & 3.50 & .76 \\
\hline Q 9: Problems in the home and with family. & 4.01 & .84 \\
\hline Q10: Poverty. & 3.89 & .87 \\
\hline Q11: School failure. & 3.92 & .92 \\
\hline Q12: Social rejection by the police and/or community. & 3.85 & .90 \\
\hline
\end{tabular}

In Q8 through Q12, most respondents generally agreed with modern criminology related to contributing factors in juvenile street gang membership. In Q10, the agreement to poverty being a contributing factor to juvenile street gang membership was strongest with survey respondents living in Region 3 ( $M=4.16)$, followed by respondents living in Region $2(M=4)$. Respondents in Region 1 had the strongest agreement to school failure as a contributing factor to juvenile criminal street gang membership (M=4.11). In Q9, most respondents among all regions agreed that problems in the home and family are the leading factors contributing to juvenile criminal street gang membership $(M=4.01)$. The reliability measurements for these survey results were statistically significant at $p<.05$.

Table4. Methods to reduce/combat juvenile street gang membership in El Paso

Mann-Whitney U Test $(N=178)$

$\mathrm{Z}$-score $=-3.32483 . P$-value $=.0009$. The result is significant at $p<.05 . U$ value $=12613.5$.

\begin{tabular}{|l|c|c|}
\hline \multicolumn{1}{|c|}{ Variable } & $\boldsymbol{M}$ & $\boldsymbol{S D}$ \\
\hline $\begin{array}{l}\text { Q13: I prefer enforcement, surveillance, control, suppression, and prosecution over community } \\
\text { treatment, prevention, and rehabilitation efforts. }\end{array}$ & 3.34 & 1.12 \\
\hline Q14: I prefer community treatment, early prevention, and rehabilitation over criminal justice efforts. & 3.75 & .94 \\
\hline
\end{tabular}

Questions Q13 and Q14 were posed as opposing statements, whereas a respondent's preference to agree with one answer would lead to a disagreement with the other answer. Most respondents demonstrated a preference towards community treatment, early prevention, and rehabilitation efforts in combating current juvenile gang membership, as opposed to enforcement, surveillance, control, suppression, and prosecution. The reliability measurements for these survey results were statistically significant at $p<.05$.

Table5. El Paso Leadership, government, and community preparedness

\begin{tabular}{|l|c|l|}
\hline $\begin{array}{l}\text { Spearman's Rho }(N=178) \\
r_{s}=0.38704, p(2 \text {-tailed })=0 .\end{array}$ \\
\hline \multicolumn{1}{|c|}{ Variable } & $\boldsymbol{M}$ & $\boldsymbol{S D}$ \\
\hline Q13: Community leaders are fully aware of El Paso street gangs and are fully & 3.22 & .90 \\
\hline
\end{tabular}




\begin{tabular}{|l|l|l|}
\hline prepared to respond to all gang issues within the community. & & \\
\hline $\begin{array}{l}\text { Q14: I am satisfied with the current response by El Paso law enforcement, social } \\
\text { services agencies, schools, etc. }\end{array}$ & 3.56 & 1.02 \\
\hline
\end{tabular}

Questions Q13 and Q14 were posed as supporting statements, whereas a respondent's preference to agree with one answer would lead to a potential agreement with the other answer. By normal standards, the association between the two variables were considered somewhat weak, but statistically significant. Survey respondents were generally satisfied with government preparedness, with the strongest agreement to local government response efforts coming from Region $5(M=4)$.

\subsection{Possible Methodological Limitations}

Although the reliability testing of the survey responses and their designed groupings demonstrated statistical significance, the number of survey respondents $(\mathrm{N}=178)$ may have produced alternate results with a larger sampling size. Different results may have resulted if sampling methods expanded beyond EPCC students to the general population of El Paso, Texas. A more thorough analysis of the results from the survey would have occurred if respondents were asked about their gender and age as well.

The reporting of the means $(M)$ by region was possible through self-reporting by the survey respondents. This limited the author's ability to independently verify the accuracy of residence reporting. These study's survey respondents may have contained bias in relation to one's age, residence and past experiences with the survey topics. Any subsequent studies expanding this research should include more data on the respondent's background and age group. Additional data collection should occur widening the range of sampling, as well as including interviews or focus groups.

\section{CONCLuSion}

This research explored criminological theories related to juvenile delinquency and their relationship to criminal street gangs. When informal social controls break down within disorganized neighborhoods, criminal cultures emerge. Disorganized communities lack the collective effort required to fight crime and disorder. Within these disorganized communities, people stabilize within in their criminal roles. After being socially labeled as a criminal, individuals are stigmatized further and dive deeper into their criminal identities. Eventually, such "criminals" become life-course persistent in their behavior and become institutionalized and excluded from future conventional roles.

When individuals cannot obtain success through conventional means, they experience strain or pressure. Within the proper social conditions, they are likely to respond to strain through anti-social behavior and crime. However, the strains leading to crime may not only be linked to goal blockage but also to the presentation of negative stimuli and absence of positive stimuli. Crime is more likely a response to strain when it results in anger and frustration.

This research also explored issues related to minorities living in low-income areas; their relationships to poverty and ultimate delinquency. Because of what the mass media portrays, most people believe that street gangs consist of mostly minorities living in low-income areas. According to Data USA (2019), El Paso, Texas has a population of about 700,000 and about $22 \%$ of the population lives in poverty. Continuing, Latinos/Hispanics represent about $70 \%$ of the population, and about $87 \%$ of El Paso's population are United States citizens. It is not difficult to find local media reports regarding gang problems in the area, yet according to the City of El Paso's official Website, the city has been voted as one of the safest cities in the country as recent as 2018 (City of El Paso, 2019). This brand of safety and one of the best places to live in has been consistent for over a decade.

Hispanics are the predominant racial/ethnic group among all gang members nationwide. Most street gang members live in low-income urban neighborhoods where juveniles are most socially isolated. However, this is not a new phenomenon. Any ethnically diverse population immigrating to the United States results in a more ethnically diverse gang population. Yet, with many of the social conditions allowing for street gangs to thrive, El Paso, Texas does not appear to suffer from violence and other related street gang crimes. In a recent January 2019 report by Channel 7 (ABC News) on El Paso homicides, the El Paso Police Department released homicide data from 1969 to 2018. Consistently, El Paso has maintained low homicide rates compared to other cities with similar population groups and typical social conditions studied on street gangs. According to the police data, over the past five years, 
El Paso has experienced an average of 18 homicides a year with a police clearance rate of about $95 \%$. According to this same report, the Federal Bureau of Investigations reports a nationwide clearance rate of homicides at about $61 \%$ (Para. 1-5).

What makes El Paso different from other similar cities? Some suggest the border wall on the United States border had a major impact in the reduction of crime, while others suggest it has to do with the efficiency and community policing philosophies of local law enforcement. It is probable both government and community efforts have an impact on the crime rates in El Paso, but this author argues that El Paso defies traditional logic on street gangs because of the culture and the positive social conditions of the area. Although El Paso has experienced long-term poverty and higher rates of first-generation migration patterns, socially disorganized areas within El Paso are uncommon. Community support for its youth is strong and educational opportunities for all students is at the forefront of El Paso leadership. According to the University of Texas at El Paso (2018), the university was recently recognized as one of the top minority degree producers by Diverse: Issues in Higher Education magazine. All public school districts in El Paso County provide dual credit courses to their high school students and El Paso Community College touts 12 Early College High Schools (EPCC, 2019). However, government and community awareness is key in preventing future growth in local street gangs.

This author believes communities which support and educate their youth in both academics and social responsibility plant a seed for long-term positive social change. It is this author's view that community leadership (public and private) and the educational institutions in El Paso, Texas lead this endeavor. Statistically, El Paso has proven that minorities and poverty have little to no influence on street gang formation compared to others, and the good people who live in El Paso choose to be socially responsible. The survey respondents (students at El Paso Community College) reflected social awareness coinciding with current criminological theory, regardless of their areas of study. Respondents generally agreed that youth are the highest risk for gang recruitment risk, but although street gang members do exist in the area, the survey respondents did not share a concern over it and were generally satisfied with community leadership, government and community preparedness in dealing with street gangs. Most survey respondents agreed with modern criminology on street gangs, and most strongly agreed with school failure as a contributing factor for juvenile street gang membership. Demonstrating social awareness, most survey respondents representing all of the regions of El Paso agreed that problems in the home and family were leading causes for youth gang membership. In this author's opinion, public awareness influences social policy. Further efforts to reduce juvenile delinquency should be focused on positive labeling, rehabilitation, increasing opportunities for high-risk adolescents, and most importantly, community and familial support.

In support of the original research question, this study suggests possible policy implications for law makers when using Rational Choice theory to support gang deterrence. Law makers should consider alternate theories exploring the negative social conditions and lack of opportunities which allow for gangs to thrive and how much public opinion and perceptions impact governments response to crime. Through the examination of student survey results, this study suggests further research exploring the deeper relationship between education, poverty, and juvenile delinquency.

\section{REFERENCES}

[1] Agnew, R. (1985). A revised strain theory of delinquency. Social Forces, 64(1).

[2] Agnew, R. (2012). Foundation for a general strain theory of crime and delinquency. Criminology, 30.

[3] Akerlof, G. \& Yellen, J. (1994). Values and public policy. The Brookings Institution. Washington, DC.

[4] Akers, R., \& Sellers, C. (2013).Criminological theories: Introduction, evaluation, and application (6th ed.). New York City, NY: Oxford University Press.

[5] Bartollas, C. \&Schmalleger, F. (2008). Juvenile Delinquency. $\left(9^{\text {th }}\right.$ ed.). NewYork, NY: Pearson.

[6] Bernburg, M., Krohn, M. \& Rivera, C. (2006). Official labeling, criminal embeddedness, and subsequent delinquency: a longitudinal test of labeling theory. Journal of Research in Crime and Delinquency. 43(1). DOI: $10.1177 / 0022427805280068$

[7] Brezina, T. \&Aragones, A. (April, 2003). Devils in disguise: the contribution of positive labeling to "sneaky thrills" delinquency. Deviant Behavior. (25). Taylor \& Francis, Inc. DOI:10.1080/01639620490484059.

[8] Broidy, L.(2001). A test of general strain theory. Criminology. 39(1). Blackwell Publishing. 
[9] City of El Paso. (2017). Agenda item: department head's summary form. Retrieved from: http://agenda. elpasotexas.gov/sirepub/cache/2/uy54sii0j2jlzwrjyaykmxps/19482803022019072549583.PDF

[10] City of El Paso. (2019). Data and statistics: recognitions and achievements. Retrieved from: https://www.elpasotexas.gov/economic-development/business-services/data-and-statistics

[11] Data USA. (2019). El Paso, Texas. Retrieved from: https://datausa.io/profile/geo/el-paso-tx/

[12] Decker, S. (2003). Policing gangs and youth violence. Belmont, CA: Wadsworth.

[13] Delaney, T. (2014). American street gangs. (2 ${ }^{\text {nd }}$ ed.).Upper Saddle River, NJ: Pearson Publishing, Inc.

[14] Desilver, Drew. (2014). Who's poor in America? 50 years into the 'war on poverty', a data portrait. Pew Research Center. Retrieved from: http://www.pewresearch.org/fact-tank/2014/01/13/whos-poor-inamerica-50-years-into-the-war-on-poverty-a-data-portrait/

[15] El Paso Community College. (2019). Early college high school. Retrieved from: https://www.epcc.edu /Academics/DualCredit/early-college-high-school

[16] Greene, J., \&Pranis, K. (2007). Gang wars: The failure of enforcement tactics and the need for effective public safety strategies. Justice Policy Institute. Washington, DC

[17] Howell, J. \&Egley, A. (April, 2012). Highlights of the 2010 National Youth Gang Survey. Office of Juvenile Justice and Delinquency Prevention. Office of Justice Programs, U.S. Department of Justice.

[18] Kaylen, M. \&Pridemore, W. (December, 2011). A reassessment of the association between social disorganizeation and youth violence in rural areas. Social Science Quarterly. 92(4). DOI: 10.1111/j.15406237.2011.0080.x

[19] Klein, M., \&Maxson, C. (2006). Street gang patterns and policies.New York: Oxford University Press.

[20] Klepper, S., \& Nagin, D. (1989). The deterrent effect of perceived certainty and severityof punishment revisited. Criminology. 27, 721-746. DOI: 10.1111/j. 1745-9125.1989.tb01052.x

[21] Knight, G., Losoya, S., Cho, Y., Williams, J., \& Cota-Robles, S. (2012). Ethnic identity and offending trajectories among Mexican American juvenile offenders: gang membership and psychosocial maturity. Journal of Research on Adolescence.22(4).

[22] KVIA-ABC 7. (2019). Crime: el paso police release murder statistics from 1960 to 2018. Retrieved from: https://www.kvia.com/crime/here-are-el-paso-s-murder-statistics-from-1960-to-2018/978417058

[23] Jacobs, B. (2010). Deterrence and deterrability. Criminology. American Society of Criminology. 48(2).

[24] Job Corps. (n.d.). Statutory authority. Retrieved from: http://http://www.jobcorps.gov/AboutJobCorps/ authority.aspx

[25] Jones, L. (2004). Sir robert peel's nine principles: their relevance to campus policing in the $21^{\text {st }}$ century. Campus Law Enforcement Journal, 34(3). Retrieved from: https://www.ncjrs.gov/app/publications /ID=206158

[26] Lee, G., Akers, R. \& Borg, M. (2004). Social learning and structural factors in adolescent substance use. Western Criminology Review. 5(1).

[27] Maxson, C, Matsuda K. \&Hennigan, K. (2009). "Deterrability" among gang and nongang juvenile offenders: are gang members more (or less) deterrable than other juvenile offenders? Crime and Delinquency. Sage Publications.com. DOI: 10.1177/0011128709343137

[28] Merton, R. (1968). Social theory and social structure. Glencoe, IL: Free Press.

[29] McElrath, Y., Chriqui, J., Bates, H., \& McBride, D. (2014). Do state policies matter in prosecutor-reported juvenile marijuana case disposition? Crime and Delinquency.60(3). DOI: 10.1177/0011128709348457.

[30] Miller, J. (November, 1998). Gender and victimization risk among young women in gangs. Journal of Research in Crime and Delinquency. 35(4). Sage Publications, Inc.

[31] Mui, H., Sales, P. \& Murphy, S. (August, 2013). Everybody's doing it: initiation to prescription drug misuse. Journal of Drug Issues. DOI: 10.1177/0022042613497935

[32] O’Deane, M. (2011). Remedies to curb gang-related crimes. Boca Raton, FL. CRC Press.

[33] Papchristou v. City of Jacksonville, 405 U.S. 156 (1972)

[34] Plummer, K. (n.d.). Labeling theory: historical, conceptual, and theoretical issues. Volume 1. Retrieved from: http://www.sjsu.edu/people/james.lee/courses/soci152/s1/ajreading10labeling.pdf

[35] Rebovich, D., Coyle, K. \&Schaaf, J. (October, 1993). Local prosecution of organized crime: the use of state RICO statutes. Office of Justice Programs, Bureau of Justice Statistics. U.S. Department of Justice.

[36] Sheley, J., Zhang, J., Brody, C. \& Wright, J. (1995). Gang organization, gang criminal activity, and individual gang members' criminal behavior. Social Science Quarterly. 76(1).

[37] Sherman, L., Gottfredson, D., MacKenzie, D., Eck, J., Reuter, P. \&Bushway, S. (1998). Preventing crime: what works, what doesn't, what's promising. Research in Brief. Department of Justice, National Institute of Justice. Washington, DC. Retrieved from: http://files.eric.ed.gov/fulltext/ED423321.pdf 
[38] Shuttlesworth v. City of Birmingham, 394 U.S. 147 (1969)

[39] Texas Department of Public Safety. (2017). Texas gang threat assessment. Retrieved from: http://www.dps .texas.gov/director_staff/media_and_communications/2017/txgangthreatassessment201707.pdf

[40] The Office of Juvenile Justice and Delinquency Prevention [OJJDP]. (1999). Criminal gangs in america: question and answer review of gang related activities. Supreme Court Debates. EBSCO Publishing.

[41] Tonry, M. (2011). The oxford handbook of crime and criminal justice. Oxford University Press, Inc.

[42] United States Census Bureau. (2014). African american population. Retrieved from https://www.censu s.gov/ newsroom/releases/archives/facts_for_features_special_editions/cb14-ff03.html

[43] University of Texas, El Paso. (2019). UTEP ranked a top degree producer for hispanic students. Retrieved from:https://www.utep.edu/newsfeed/campus/UTEP-Ranked-a-Top-Degree-Producer-for-Hispanic-Stude nts.html

\section{AUTHOR'S BIOGRAPHY}

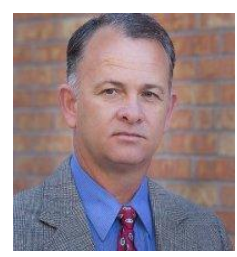

Scott Christopher Mann, Assistant Professor of Criminal Justice at El Paso Community College. Master degrees in Criminal Justice, and Administration of Justice and Security. Research interests include Criminal Justice, Criminology, and online education. He is also a graduate of the FBI National Academy (188th Session), the Law Enforcement Management Institute of Texas (LEMIT), and a retired law enforcement officer from the Great State of Texas.

Citation: Scott Christopher Mann. "Criminal Street Gangs: Public Perceptions of Local Gang Issues." International Journal of Humanities Social Sciences and Education (IJHSSE), vol 6, no. 3, 2019, pp. 68-82 doi: http://dx.doi.org/10.20431/2349-0381.0603009.

Copyright: () 2019 Authors. This is an open-access article distributed under the terms of the Creative Commons Attribution License, which permits unrestricted use, distribution, and reproduction in any medium, provided the original author and source are credited. 